\section{DIARY}

\section{APRIL}

BDA Seminar - Growing your practice in challenging times

Date: 23 April 2010

Venue: Leeds Marriott Hotel, Leeds

HC2010 health informatics conference and exhibition

Date: $27-29$ April 2010

Venue: International Conference

Centre (ICC), Birmingham

www.hc2010.co.uk

\section{MAY}

Dental Sedation Teachers

Group Annual Symposium 2010

Date: 14-15 May 2010

Venue: Dublin Dental School \& Hospital,

Trinity College Dublin, Ireland

Email: mary.clarke@dental.tcd.ie

www.dstg.co.uk

British Dental Conference

and Exhibition 2010

Date: 20-22 May 2010

Venue: Arena and Convention Centre,

Liverpool

Tel: 08701666625

Email: bda@delegate.com

www.bda.org

\section{JUNE}

Annual Meeting of the European

Society of Dental Ergonomics

Date: 4-5 June 2010

Venue: Ghent University Hospital,

Ghent, Belgium

Email: secretary-general @esde.org

www.esde.org

Training essentials - Managing stress

in yourself and your team

Date: 17 June 2010

Venue: BDA, London

Email: events@bda.org

Welsh Rural Postgraduate Unit,

Institute of Rural Health,

11th Annual Rural Dental Conference

Date: 25 June 2010

Venue: Gregynog Hall, Newtown, Mid Wales Tel: 01686650800

BDA Seminar - Introduction to being an associate

Date: 25 June 2010

Venue: BDA, London

www.bda.org/events

\title{
SAFEGUARDS INTRODUCED FOR PROVISION OF INJECTABLE COSMETIC TREATMENTS
}

Injectable cosmetic treatments, including dermal fillers and botulinum toxin, are to be regulated in the form of a new Government backed registration scheme.

The registration, certification and inspection scheme has been developed by the injectable cosmetics industry with the encouragement of Ministers to safeguard patients from treatments carried about by unqualified rogue practitioners.

The Independent Healthcare Advisory Services (IHAS) will be running the industry-led shared regulation scheme. There are currently an estimated 5,000 facilities carrying out an estimated 200,000 treatments a year in the UK. As treatments are elective, until now providers of injectable cosmetic treatments have fallen outside the scope of watchdogs at the Care Quality Commission (CQC).

Dr Andrew Vallance-0wen, Chair of IHAS Shared Regulation Group said, 'This is excellent news for consumers and properly qualified practitioners. With growth of an estimated 25\% of treatments carried out last year alone, the industry and the Department of Health recognised the need to safeguard patients by creating a system of registration and certification to reduce the risk of poor practice within the sector.'

Health Minister Mike 0’Brien said, 'Quality marking the organisations that provide injectable cosmetic treatments, such as Botox and wrinkle fillers, will help protect the public from unscrupulous operators. It will clearly mark those who uphold the highest standards the industry can provide.'

The General Dental Council, General Medical Council and Nursing and Midwifery Council have jointly supported any appropriate measures to enhance protection of patients and the public which complement their standards and guidance for healthcare professionals.

The IHAS Quality Assurance Scheme will include the registration of organisations where practitioners are providing treatment, as well as registering sole practitioners working in facilities where injectable cosmetic treatments are provided. It will only register practitioners who are registered adult nurses, doctors or dentists over the next few months.

The Scheme will include a dedicated website which will list organisations and practitioners that have been accepted for registration and certification, signposting patients to providers who are offering high standard care.

All providers will be charged a registration scheme fee, with all funds generated being reinvested into the running of the scheme. The IHAS Quality Assurance Scheme will require practitioners and organisations to seek re-certification every year to ensure standards are maintained.

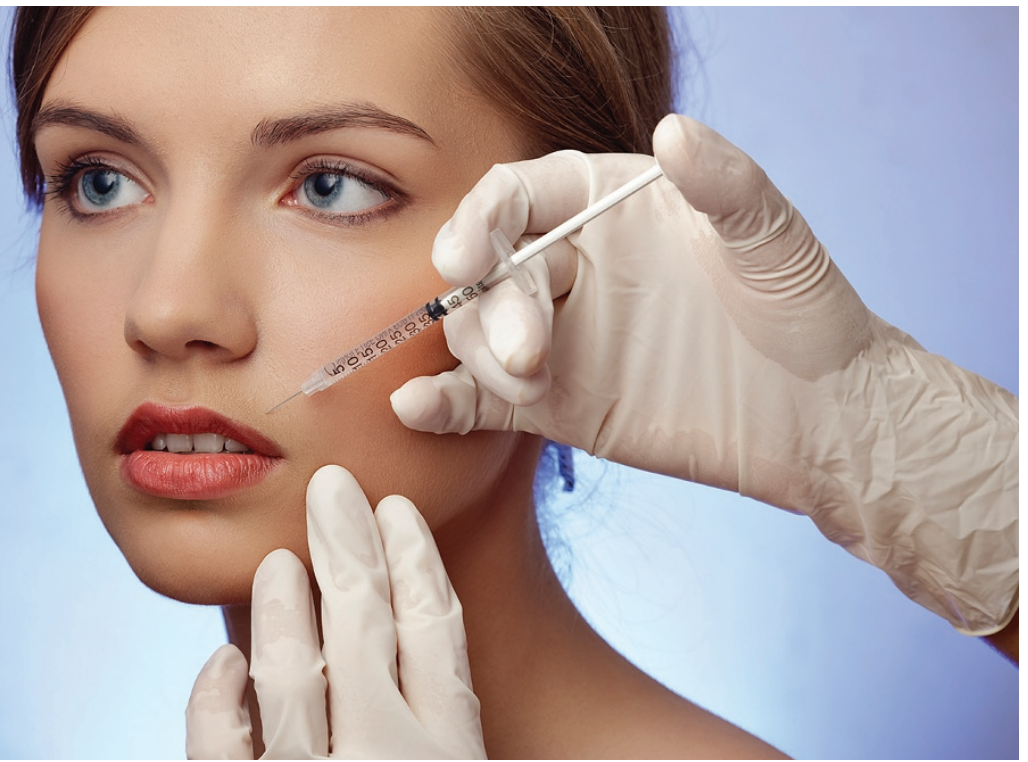

